\title{
Summary of Hydrogeology and Simulation of Ground-Water Flow and Land-Surface Subsidence in the Northern Part of the Gulf Coast Aquifer System, Texas
}

The northern part of the Gulf Coast aquifer system in Texas. which includes the Chicot, Evangeline, and Jasper aquifers, supplies most of the water used for industrial, municipal, agricultural, and commercial purposes for an approximately 25,000 square-mile $\left(\mathrm{mi}^{2}\right)$ area that includes the Beaumont and Houston metropolitan areas. The area has an abundant amount of potable ground water, but withdrawals of large quantities of ground water have resulted in potentiometric-surface declines in the Chicot, Evangeline, and Jasper aquifers and land-surface subsidence from depressurization and compaction of clay layers interbedded in the aquifer sediments. This fact sheet summarizes a study done in cooperation with the Texas Water Development Board (TWDB) and the Harris-Galveston Coastal Subsidence District (HGCSD) as a part of the TWDB Ground-Water Availability Modeling (or Model) (GAM) program. The study was designed to develop and test a ground-water-flow model of the northern part of the Gulf Coast aquifer system in the GAM area (fig. 1) that waterresource managers can use as a tool to address future groundwater-availability issues.

\section{Hydrogeology}

In a generalized conceptual model of the aquifer system, a fraction of the approximately 48 inches of annual rainfall enters the ground-water-flow system in topographically high outcrops of the hydrogeologic units in the northwestern part of the system. Much of the water that infiltrates to the saturated zone flows relatively short distances through shallow zones and
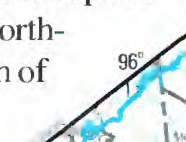

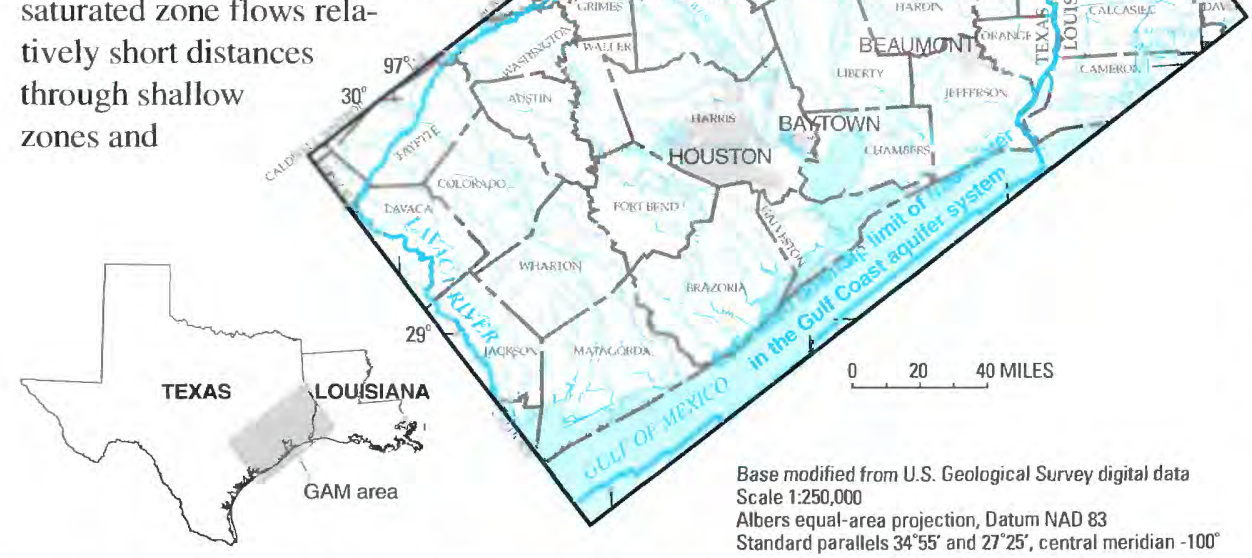

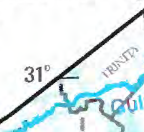
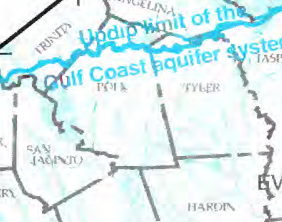

discharges to streams; the remainder of the water flows to intermediate and deep zones of the system southeastward of the outcrop areas where it is discharged by wells and by upward leakage in topographically low areas near the coast. Near the coast and at depth, saline water is present, which causes freshwater not captured by wells to be redirected upward as diffuse leakage and ultimately discharged to coastal water bodies.

From land surface downward, the Chicot aquifer, the Evangeline aquifer, the Burkeville confining unit, the Jasper aquifer, and the Catahoula confining unit are the hydrogeologic units of the Gulf Coast aquifer system. (The Catahoula confining unit is assumed to be a no-flow base-of-system for simulation.) The uppermost parts of the aquifer system, which include outcrop areas, are under water-table conditions. As depth increases in the aquifer system and interbedded sand and clay accumulate, watertable conditions evolve into confined conditions. Thus the lowermost parts of the aquifer system are under confined conditions. The middle parts of the aquifer system therefore are under semiconfined conditions.
Figure 1. Loc ation of Ground-Water Availability Model (GAM) area showing boundary of the northern part of the Gulf Coast aquifer system, Texas.
Three principal areas of concentrated ground-water withdrawals from the system are in the GAM area: the largest, in terms of water withdrawn, is Harris and Galveston Counties (the Houston area). Withdrawals there were about 463 million gallons per day (Mgal/d) in 1996. The second principal area of withdrawals is the coastal irrigation area centered in Wharton and Jackson Counties. Withdrawals in Wharton County, which historically account for about 70 to 80 percent of the irrigation total for the area, were about $183 \mathrm{Mgal} / \mathrm{d}$ in 2000. The third principal area of withdrawals is the Evadale-Beaumont area. Industrial withdrawals are associated with wood-pulp processing at Evadale in southwestern Jasper County, and publicsupply withdrawals are from the Beaumont well field in southeastern Hardin County. Withdrawals there were about $44 \mathrm{Mgal} / \mathrm{d}$ in 2000 .

Before appreciable ground-water withdrawals from the system in the GAM area, 
the potentiometric surfaces in the confined parts of the aquifers were higher than land surface in places. Ground-water development has caused substantial (as much as 350 feet [ft]) declines of the potentiometric surfaces of the aquifers and subsequent landsurface subsidence (more than $10 \mathrm{ft}$ ) primarily in the Houston area.

\section{Simulation of Ground-Water Flow and Land-Surface Subsidence}

The U.S. Geological Survey MODFLOW finite-difference model was used to simulate ground-water flow and land-surface subsidence. The model comprises four layers. one for each of the hydrogeologic units of the aquifer system except the Catahoula confining unit, the no-flow base-of-system. Each layer consists of 137 rows and 245 columns of uniformly spaced grid blocks, each block representing $1 \mathrm{mi}^{2}$.

The northwestern boundaries of the hydrogeologic units are the northwestern extent of the updip outcrop sediments for each unit. The downdip limit of freshwater (dissolved solids concentration of $10,000 \mathrm{mg} / \mathrm{L}$ ) was chosen as the southeastern boundary of flow in each hydrogeologic unit. The southwestern-northeastern lateral boundaries of the hydrogeologic units were selected to coincide with ground-water-flow divides associated with major streams - the Lavaca River to the southwest and the Sabine River to the northeast.

The MODFLOW general-head boundary package was used to simulate recharge and discharge in the outcrops of the hydrogeologic units. This package allows the water table of an aquifer system to function as a head-dependent flux (flow per unit area) boundary. Flow between streams and the aquifer system was not explicitly simulated by imposing sinks along streams in the model. The rationale for this decision is that the general-head boundary package, assuming the model is adequately calibrated, would account for stream discharge to the level of accuracy that such discharge is known.

The initial values of hydraulic properties associated with ground-water flow were selected on the basis of findings of numerous previous studies and hydrologic judgment. Simulations were made under transient conditions from 1891 through 2000 for 68 withdrawal (stress) periods of variable, but mostly annual. length. Historical ground-water-withdrawal data-municipal, manufacturing, mining, power generation, livestock, irrigation, and countyother-were compiled from numerous sources and distributed to the appropriate model layers and grid blocks by various methods.

Simulation of land-surface subsidence (actually, compaction of clays) and the release of water from storage in the clays of the Chicot and Evangeline aquifers was accomplished using the Interbed-Storage Package designed for use with the MODFLOW model. Subsidence and compaction of clays in the Jasper aquifer and the Burkeville confining unit were not simulated because the sediments of those units are more consolidated relative to the sediments of the Chicot and Evangeline aquifers and less head decline has occurred in those units.

\section{Model Calibration}

The GAM was calibrated by trial-and-error adjustment of selected model input data (the aquifer properties that control water flow, recharge, discharge, and storage) in a series of transient simulations until the model output (potentiometric surfaces, land-surface subsidence, selected water-budget components) reasonably reproduced field measured (or estimated) aquifer responses. The calibration objective was to minimize the differences between simulated and measured aquifer responses. Model calibration comprised four elements: (1) Qualitative comparison of simulated and measured potentiometric surfaces in the aquifers for 1977 and 2000; and quantitative comparison of simulated and measured potentiometric surfaces by computation and areal distribution of the root-mean-square (RMS) error between simulated and measured heads. (2) Comparison of simulated and measured hydrographs from wells in the aquifers in the Houston area, the coastal irrigation area, and selected counties away from those areas of withdrawal. (3) Comparison of simulated water-budget components - primarily recharge and discharge- to estimates of physically reasonable ranges of actual water-budget components; and comparison of simulated distributions of recharge and discharge in the outcrops of aquifers to estimates of physically reasonable distributions based on knowledge of the hydrology of the aquifer system. (4) Comparison of simulated land-surface subsidence from predevelopment to 2000 to measured land-surface subsidence from 1906 through 1995.

\section{Model Results}

For the Chicot aquifer, transmissivities after calibration range from negligible to about 77,000 feet squared per day $\left(\mathrm{ft}^{2} / \mathrm{d}\right)$. For the Evangeline aquifer, transmissivities range from negligible to about $43.000 \mathrm{ft}^{2} / \mathrm{d}$. Transmissivities near the maximums for both aquifers occur in only a few grid blocks. Transmissivities of the Burkeville confining unit (unadjusted from initial values during calibration) are very small (maximum about $8 \mathrm{ft}^{2} / \mathrm{d}$ ). For the Jasper aquifer, transmissivities range from negligible to about $14,500 \mathrm{ft}^{2} / \mathrm{d}$.

Storativities of the Chicot and Evangeline aquifers $\left(1 \times 10^{-4}\right.$ to 0.2 and $4 \times 10^{-5}$ to 0.2 , respectively) reflect aquifer conditions from confined to semiconfined to water table. Chicot aquifer storativities generally are largest in the updip, outcrop areas where water-table conditions prevail. Storativities of the Burkeville confining unit and the Jasper aquifer $\left(1 \times 10^{-5}\right.$ to $5 \times 10^{-2}$ and $2 \times 10^{-5}$ to 0.2 . respectively) also are generally largest in the updip, outcrop areas where water-table conditions prevail.

The simulated potentiometric surfaces of the Chicot, Evangeline, and Jasper aquifers for 1977 show general agreement with the measured potentiometric surfaces (or with measured point head data in areas where data are sparse). The RMS errors for the aquifer potentiometric surfaces, which reflect the average difference between 1977 simulated and measured heads, were about $34 \mathrm{ft}$ for the Chicot aquifer, about $43 \mathrm{ft}$ for the Evangeline aquifer, and about $47 \mathrm{ft}$ for the Jasper aquifer. The RMS errors are about 7, 8, and 17 percent, respectively, of the total range in measured heads for the respective aquifers. 
The simulated potentiometric surfaces of the Chicot, Evangeline, and Jasper aquifers for 2000 also show general agreement with the measured potentiometric surfaces (or with measured point head data in areas where data are sparse). The simulated and measured 2000 Chicot and Evangeline potentiometric surfaces, compared with those for 1977 , show substantial shifts to the northwest in the major cones of depression in the Houston area, which reflect shifts northwestward of the centers of withdrawals during 1977-2000. The measured 2000 Chicot aquifer potentiometric surface also shows about $100 \mathrm{ft}$ of recovery in the major cone of depression, which is consistent with the overall reduction in withdrawals from the system during 1977-2000. In the EvadaleBeaumont area, the simulated 2000 cone of depression in the Evangeline aquifer is larger and about $150 \mathrm{ft}$ deeper than the cone of 1977. Simulated withdrawals in the area increased about 85 percent between 1977 and 2000. The RMS errors for the three aquifer potentiometric surfaces for 2000 were about $31 \mathrm{ft}$ for the Chicot aquifer. about $40 \mathrm{ft}$ for the Evangeline aquifer, and about $34 \mathrm{ft}$ for the Jasper aquifer. The RMS errors are about 8,6, and 11 percent, respectively, of the total range in measured heads for the respective aquifers.

Simulated and measured hydrographs for the three aquifers in the Houston area (for example, fig. 2a) match closely relative to the ranges of change; those from the Chicot aquifer in the coastal irrigation area (for example, fig. 2b) match less closely; and those for the aquifers away from the Houston and coastal irrigation areas (for example in the Evadale-Beaumont withdrawal area, fig. 2c) match with varying degrees of closeness. For hydrographs in which the match between simulated and measured heads is less close than others, the trends in simulated and measured heads generally are similar.

For calibrated 1977 conditions, simulated net recharge is 555 cubic feet per second $\left(\mathrm{ft}^{3} / \mathrm{s}\right)(0.40$ inches per year [in/yr] $)$ in the Chicot aquifer outcrop, $19 \mathrm{ft}^{3} / \mathrm{s}(0.12 \mathrm{in} / \mathrm{yr})$ in the Evangeline aquifer outcrop, negligible in the Burkeville confining unit outcrop, and $14 \mathrm{ft}^{3} / \mathrm{s}(0.06 \mathrm{in} / \mathrm{yr})$ in the Jasper aquifer outcrop. In terms of a water balance (within $5 \mathrm{ft}^{3} / \mathrm{s}$ ) for the entire system in 1977 . $757 \mathrm{ft}^{3} / \mathrm{s}$ of recharge plus $1,082 \mathrm{ft}^{3} / \mathrm{s}$ from depletion of sand storage $\left(742 \mathrm{ft}^{3} / \mathrm{s}\right)$ and inelastic compaction of clays $\left(340 \mathrm{ft}^{3} / \mathrm{s}\right)$ is offset by $169 \mathrm{ft}^{3} / \mathrm{s}$ of natural discharge and $1,670 \mathrm{ft}^{3} / \mathrm{s}(1,080 \mathrm{Mgal} / \mathrm{d})$ of withdrawals. Thus in 1977, net recharge supplied about 35 percent of withdrawals, depletion of sand storage about 45 percent, and inelastic compaction of clays about 20 percent.

For calibrated 2000 conditions (fig. 3), simulated net recharge is $769 \mathrm{ft}^{3} / \mathrm{s}(0.55 \mathrm{in} / \mathrm{yr})$ in the Chicot aquifer outcrop, $18 \mathrm{ft}^{3} / \mathrm{s}$ $(0.11 \mathrm{in} / \mathrm{yr})$ in the Evangeline aquifer outcrop, negligible in the Burkeville confining unit outcrop, and $17 \mathrm{ft}^{3} / \mathrm{s}(0.07 \mathrm{in} / \mathrm{yr})$ in the Jasper aquifer outcrop. In terms of a water balance (within $5 \mathrm{ft}^{3} / \mathrm{s}$ ) for the entire system in $2000,965 \mathrm{ft}^{3} / \mathrm{s}$ of recharge plus $516 \mathrm{ft}^{3} / \mathrm{s}$ from depletion of sand storage $\left(410 \mathrm{ft}^{3} / \mathrm{s}\right)$ and inelastic compaction of clays $\left(106 \mathrm{ft}^{3} / \mathrm{s}\right)$ is offset by $161 \mathrm{ft}^{3} / \mathrm{s}$ of natural discharge and $1,322 \mathrm{ft}^{3} / \mathrm{s}(854 \mathrm{Mgal} / \mathrm{d})$ of withdrawals. Thus in 2000 , net recharge supplied 61 percent of withdrawals, depletion of sand storage 31 percent, and inelastic compaction of clays 8 percent.

The most notable differences between the simulated waterbudget components of 1977 and 2000, besides the fact withdrawals
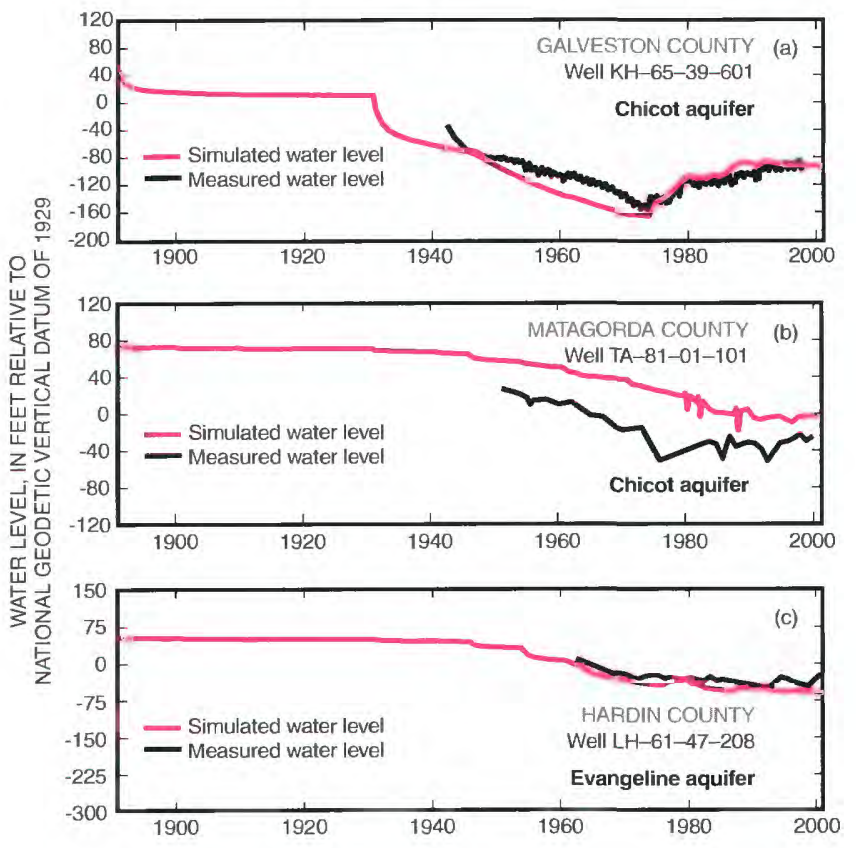

Figure 2. Hydrographs showing simulated and measured water levels in selected observation wells screened in the aquifer system in the Ground-Water Availability Model area.

were about 21 percent less in 2000, are the increase in the percentage of withdrawals supplied by recharge and the decrease in the percentage of water supplied by depletion of storage and inelastic compaction of clays between 1977 and 2000. The simulated recharge rates for the GAM for 1977 and 2000 appear to be generally comparable to estimates of recharge rates from previous studies involving all or parts of the Gulf Coast aquifer system in Texas.

The match between simulated and measured land-surface subsidence from predevelopment to near present day in the HarrisGalveston-Fort Bend County area, where compaction of subsurface material and thus subsidence has been monitored continuously since the 1970s, is close. As much as $10 \mathrm{ft}$ of subsidence has occurred in southeastern Harris County near the northern end of Galveston Bay. A larger geographic area encompassing the maximum land-surface-subsidence area and much of central to southeastern Harris County has subsided at least $6 \mathrm{ft}$.

Away from the Harris-Galveston-Fort Bend County area, subsidence of as much as $3 \mathrm{ft}$ was simulated in the EvadaleBeaumont withdrawal area in southwestern Jasper County. No subsidence was simulated in the coastal irrigation area centered in southern Wharton County. No recent (near 2000) subsidence measurements are available for either area, although small amounts of subsidence (less than $2 \mathrm{ft}$ ) have been documented historically in both areas.

\section{Model Limitations}

Several factors limit, or detract from, the ability of the GAM to reliably predict aquifer responses to future conditions. For example, associated with each of the input datasets is a level of uncertainty and a degree of bias, neither of which is quantitatively 


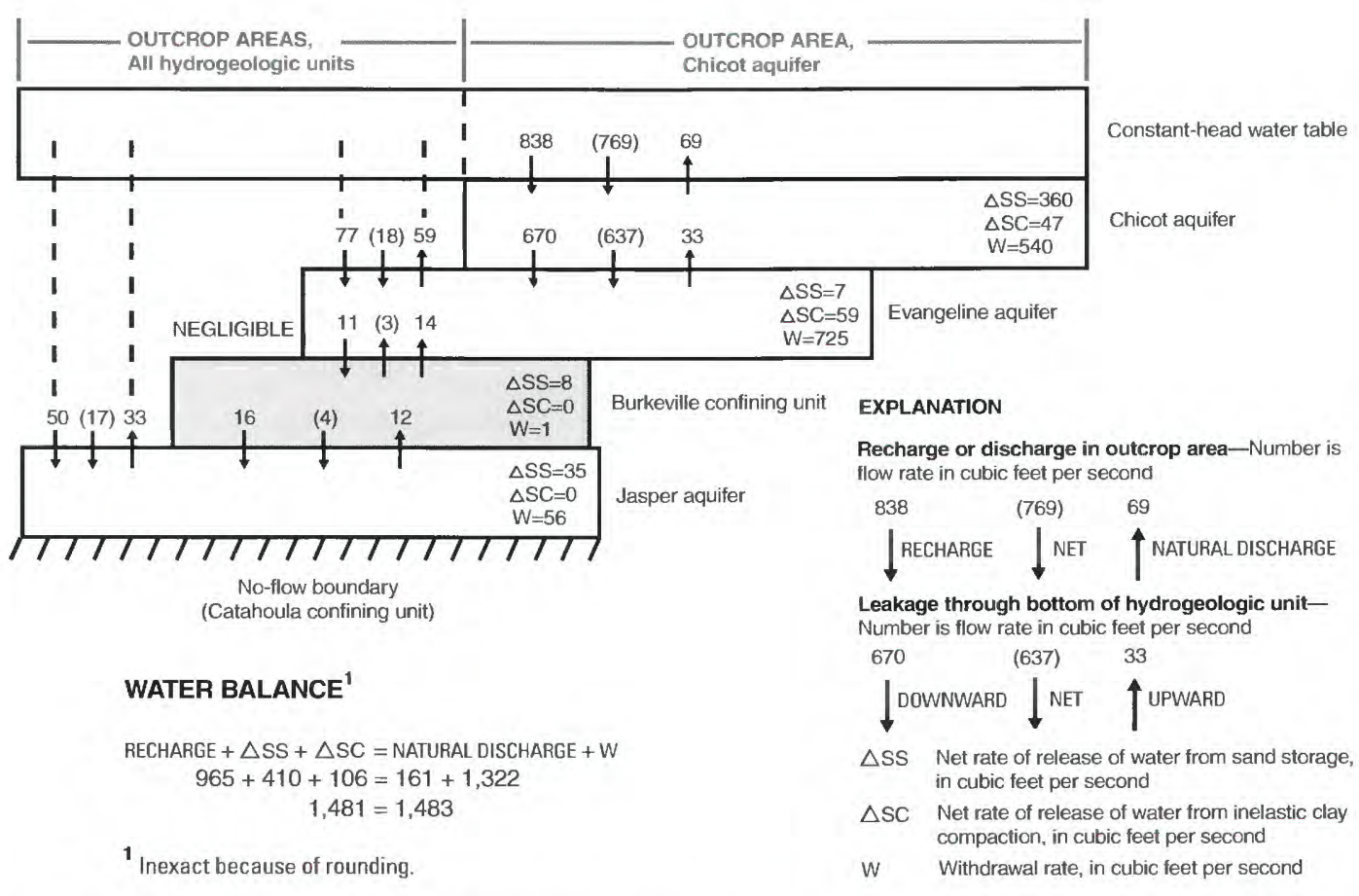

Figure 3. Simulated 2000 water-budget components of the hydrogeologic units in the aquifer system in the Ground-Water Availability Model area.

known. The uncertainty arises from the fact that point measurements or estimates of the input data represent regions around the points. The bias originates from the facts that some properties are better known than others and individual properties are better known in some areas than others. The result is that the optimum (but non-unique) distributions of input data arrived at through calibration, or history matching, are distributions of effective properties, not actual properties. In all likelihood, the property distributions reflect the order of magnitude of the real-system properties, but not the true distributions of the real-system properties. What can be said about the distributions of aquifersystem properties after calibration is that, collectively, they are one set of probably many sets of input data that allows the model to reasonably reproduce selected historical heads, subsidence, and flows. This implies that the reliability of the model for predictive simulation is uncertain.

The GAM is a regional-scale model, and as such it is intended for regional-scale rather than local-scale analyses. Discretization of the GAM area into $1-\mathrm{mi}^{2}$ grid blocks in which aquifer properties and conditions are assumed to be averages over the area of each grid block precludes site-specific analyses. Discretization detracts in another way as well: Because flow that enters and exits the real system within the area encompassed by a single grid block cannot be simulated except by superposition of sources or sinks, the model does not simulate total recharge (and thus total [realsystem] ground-water flow). What this implies is that any simulated components of flow not explicitly specified (for example, natural recharge and discharge) will be less than their real-system counterparts.

\section{- Mark C. Kasmarek and James L. Robinson}

\section{This fact sheet is based on the report}

Kasmarek, M.C., and Robinson, J.L., 2004, Hydrogeology and simulation of ground-water flow and land-surface subsidence in the northern part of the Gulf Coast aquifer system, Texas: U.S. Geological Survey Scientific Investigations Report 2004-5102, $111 \mathrm{p}$.

\section{For additional information, please contact}

District Chief

U.S. Geological Survey

8027 Exchange Dr.

Austin, TX 78754-4733

E-mail: dc_tx@usgs.gov

Phone: (512) 927-3500

FAX: (512) 927-3590

World Wide Web: http://tx.usgs.gov/ 